\title{
Skor Prediksi Kematian Pneumonia pada Anak Usia di Bawah Lima Tahun
}

Ambarsari S. N. Latumahina, Rina Triasih, Kristia Hermawan

Bagian Ilmu Kesehatan Anak Fakultas Kedokteran Universitas Gadjah Mada Yogyakarta

Latar belakang. Pneumonia merupakan penyebab utama kematian pada anak usia di bawah lima tahun di negara berkembang. Pengembangan sistem skor yang sederhana untuk memprediksi kematian pada pneumonia dapat meningkatkan kualitas pelayanan dan menurunkan angka kematian anak akibat pneumonia.

Tujuan. Menyusun skor prediksi kematian pada anak dengan pneumonia.

Metode. Penelitian kohort retrospektif pada anak (umur 2 bulan sampai 5 tahun) yang dirawat di RSUP Dr. Sardjito dengan pneumonia sejak Januari 2009 sampai Desember 2014. Anak dengan rekam medis tidak lengkap atau dengan infeksi HIV dieksklusi. Digunakan metode Spiegelhalter Knill-Jones untuk penyusunan skor kematian. Prediktor kematian dengan likelihood ratio (LHR) $\leq 0,5$ atau $\geq 2$ dimasukkan dalam sistem skor. Cut off point dari skor total ditentukan dengan kurva receiver operating characteristic (ROC).

Hasil. Di antara 225 anak yang memenuhi kriteria, 42 (18,7\%) meninggal. Prediktor kematian yang memenuhi kriteria LHR adalah usia $<6$ bulan (LHR 2,05), takikardia (LHR 2,11), saturasi oksigen (SpO2) <92\% (LHR 2,54), anemia (LHR 0,38) dan leukositosis (LHR 2,04). Skor prediksi kematian terdiri atas usia (skor $=5$ bila usia $<6$ bulan dan 0 bila $>6$ bulan); frekuensi nadi (skor=6 bila takikardia dan -8 bila normal); saturasi oksigen (skor=3 bila SpO2 <92\% dan 0 bila SpO2 $\geq 92 \%$ ); hemoglobin (skor=4 bila anemia dan -6 bila normal), leukosit (skor=3 bila leukosit dan 0 bila normal). Total skor $\geq 3$ mempunyai sensitivitas dan spesifitas terbaik, yaitu $85,7 \%$ dan $72,1 \%$.

Kesimpulan. Skor prediksi kematian pneumonia $\geq 3$ dapat digunakan untuk memprediksi kematian pada anak dengan pneumonia. Sari Pediatri 2016;18(3):214-9

Kata kunci: pneumonia, kematian, prediksi, skor

\section{Pneumonia Mortality Prediction Score for Children under Five Years of Age \\ Ambarsari S. N. Latumahina, Rina Triasih, Kristia Hermawan}

Background. Pneumonia is a leading cause of mortality in children under five years of age. Development of a simple score to predict death in pneumonia can improve the quality of care and reduce childhood mortality from pneumonia.

Objective. To develop mortality prediction score in children with pneumonia.

Methods. We conducted a retrospective cohort study of children ( 2 months to 5 years) who were admitted to Sardjito hospital with pneumonia between 2009 and 2014. Those with incomplete data and HIV infection were excluded. We used the Spiegelhalter Knill-Jones method to develop the scoring system. Factors with a likelihood ratio (LHR) $\leq 0.5$ or $\geq 2$ were retained to develop the prediction score. Cut off point of total score was determined with ROC curve.

Results. Of 225 eligible children, 42 (18.67\%) died. Factors with eligible LHR were age $<6$ months (LHR 2.05), tachycardia (LHR 2.11), SpO2 <92\% (LHR 2.54), anemia (LHR 0.38) and leukocytosis (LHR 2.04). The mortality prediction score consists of age (score $=5$ if age $<6$ months and 0 if $>6$ months); heart rate (score $=6$ if tachycardia and -8 if normal); oxygen saturation $($ score $=3$ if $\mathrm{SpO} 2<92 \%$ and 0 if SpO2 $\geq 92 \%$ ); hemoglobin (score= 4 if anemia and -6 if normal); leukocytes (score= 3 if leukocytosis and 0 if normal). A total score $\geq 3$ had the best combination of sensitivity $(85.7 \%)$ and specificity $(72.1 \%)$.

Conclusion. The pneumonia mortality prediction score $\geq 3$ can predict mortality in young children with pneumonia.

Sari Pediatri 2016;18(3):214-9

Keywords: pneumonia, mortality, prediction, score

Alamat korespondensi: Dr. Ambarsari S. N. Latumahina. Dr. Rina Triasih, SpA(K). Bagian Ilmu Kesehatan Anak, Fakultas Kedokteran, Universitas Gadjah Mada, Yogyakarta, Indonesia. Email: rina_triasih@yahoo.com,ambarlatu@gmail.com 
$\mathrm{P}$ neumonia merupakan masalah kesehatan utama pada anak, khususnya di negara berkembang. Pneumonia merupakan penyebab utama kesakitan dan kematian anak berusia di bawah lima tahun (balita). ${ }^{1}$ Insiden diperkirakan 0,29 episode per anak balita setiap tahun di negara berkembang dan 0,05 episode per anak setiap tahun di negara maju. Hal ini berarti terdapat sekitar 156 juta episode baru setiap tahun di seluruh dunia dengan 151 juta episode terdapat di negara berkembang. Sebagian kasus terjadi di India (43 juta), Cina (21 juta), Pakistan (10 juta), dan Bangladesh, Indonesia dan Nigeria (masing-masing 6 juta). Dari semua kasus, 7\%-13\% dengan gejala klinis yang dapat mengancam jiwa dan membutuhkan rawat inap. ${ }^{2}$

Angka kematian akibat pneumonia pada anak masih tinggi. Diperkirakan sekitar 19\% dari seluruh kematian anak berusia di bawah lima tahun di seluruh dunia meninggal akibat pneumonia, lebih dari $70 \%$ berlangsung di Afrika dan Asia Tenggara. ${ }^{1,2}$ Data dari Indonesia menunjukkan bahwa pada tahun 2013 terdapat 571.547 balita pneumonia, angka kematian sebesar $1,19 \%$. Angka kematian kelompok bayi lebih tinggi (2,89\%) dibandingkan kelompok umur 1-4 tahun $(0,20 \%){ }^{3}$ Mengingat, pneumonia merupakan penyebab utama kematian pada balita, global action plan for the prevention and control of pneumonia and diarrhoea (GAPPD) memprioritaskan pengendalian pneumonia untuk mencapai target millenium development goals ke empat (MDGs 4). Prioritas GAPPD menurunkan angka insiden pneumonia berat dan diare sebesar $75 \%$ pada tahun 2025 dibanding tahun 2010 dengan tujuan utama untuk mengakhiri kematian anak karena pneumonia dan diare pada tahun 2025 (GAPPD WHO-UNICEF, 2013).

Penelitian ini bertujuan menyusun sistem skor yang sederhana untuk memprediksi kematian pada anak dengan pneumonia, khususnya balita. Skor prediksi kematian pneumonia (SPKP) ini diharapkan dapat membantu dokter mengenali pasien dengan risiko tinggi kematian sehingga dapat dilakukan antisipasi dini untuk mencegah kematian, misalnya segera merujuk ke fasilitas pelayanan kesehatan yang lebih tinggi. Di samping itu, skor ini juga dapat dipakai sebagai acuan dokter untuk memberikan edukasi ke keluarga pasien mengenai prognosis.

\section{Metode}

Dilakukan penelitan kohort retrospektif pada anak usia 2 bulan - 5 tahun yang dirawat di RSUP Dr. Sardjito dengan pneumonia sejak Januari 2009 sampai Desember 2014. Data dikumpulkan dari rekam medis pasien dengan kuesioner, meliputi data demografi (usia, jenis kelamin, tanggal masuk dan keluar rumah

Tabel 1. Kriteria kondisi klinis dan laboratoris

\begin{tabular}{lc}
\hline Kriteria & Nilai \\
\hline Napas cepat (Kriteria WHO, 1984) & $\mathrm{RR}>50 \mathrm{x} / \mathrm{menit}$ \\
$0-<12$ bulan & $\mathrm{RR}>40 \mathrm{x} / \mathrm{menit}$ \\
$1-5$ tahun & \\
Takikardia (kriteria American Academy of Pediatrics, 2005) & $\mathrm{HR}>100-180 \mathrm{x} / \mathrm{menit}$ \\
$1-<12$ bulan & $\mathrm{HR}>70-110 \mathrm{x} / \mathrm{menit}$ \\
$1-5$ tahun & $\mathrm{Hb}<11 \mathrm{~g} / \mathrm{dL}$ \\
Anemia (kriteria WHO, 2011) & \\
6-59 bulan & \\
Leukositosis/leukopenia & \\
(kriteria American Academy of Pediatrics, 2012) & $6.000-17.500 / \mathrm{mm}^{3}$ \\
$2-<6$ bulan & $6.000-17.000 / \mathrm{mm}^{3}$ \\
6 bulan $-<2$ tahun & $5.000-15.500 / \mathrm{mm}^{3}$ \\
$2-6$ tahun & \\
Trombositosis/trombositopenia & \\
(kriteria American Academy of Pediatrics, 2012) & \\
6 bulan -12 tahun & $150.000-350.000 / \mathrm{mm}^{3}$ \\
\hline
\end{tabular}


sakit, rujukan), riwayat kehamilan dan persalinan (usia kehamilan dan berat badan lahir), gejala klinis (demam, batuk, pilek, sesak napas, bibir biru, diare dan muntah), berat badan, tinggi badan, pemeriksaan fisik pada saat masuk rumah sakit (frekuensi nadi, frekuensi napas, suhu, saturasi oksigen (SpO2), retraksi, krepitasi, wheezing, ronki), hasil pemeriksaan darah rutin (kadar hemoglobin, jumlah leukosit, jumlah trombosit), hasil foto dada (normal, infiltrat, konsolidasi, efusi, atelektasis, pneumothoraks), penyulit atau komplikasi (distress respirasi, prolonged fever, sepsis, efusi pleura, empiema), penyakit penyerta (kelainan jantung bawaan, meningitis/ensefalitis, leukemia, gizi buruk dan diare), serta luaran pneumonia (hidup atau mati). Penentuan kriteria napas cepat, takikardi, anemia, leukositosis/leukopenia dan trombositosis/ trombositopenia dinilai sesuai dengan umur (Tabel 1). Pasien dengan data rekam medis yang tidak lengkap atau dengan infeksi HIV tidak diikutkan dalam penelitian.

Perhitungan besar sampel digunakan uji likelihood ratio dengan membandingkan dua proporsi independen. Dengan nilai a (level of significance) $=0,5$ (twosided), power $=80 \%$, odds ratio $(\mathrm{OR})=3(\mathrm{OR}$ minimal yang dianggap bermakna), dan prevalensi pneumonia pada populasi sebesar $15 \%$, didapatkan estimasi besar sampel minimal adalah 150 .

Metode Spiegelhalter Knill-Jones digunakan untuk menyusun skor prediksi kematian. Langkah pertama adalah menghitung likelihood ratio (LHR) positif maupun LHR negatif masing-masing prediktor kematian. Selanjutnya, LHR tersebut dikonversi menggunakan skala logaritmik untuk mendapatkan skor kasar (crude weight). Prediktor dengan LHR $\leq 0,5$ atau $\geq 2$ akan diperhitungkan dalam analisis multivariat menggunakan metode Spiegelhalter Knill-Jones untuk mendapatkan adjusted weight. Nilai adjusted weight dipakai sebagai nilai skor untuk masing-masing variabel. Masing-masing pasien diskor dan hasilnya dibandingkan dengan outcome akhir (hidup atau mati). Cut off point dari skor total prediksi kematian ditentukan dengan kurva receiver operating characteristic (ROC). Dengan melihat nilai area under curve (AUC) $>0,8$, skor prediksi kematian pneumonia dianggap memiliki nilai akurasi yang tinggi untuk dapat menjadi sebuah sistem skor sederhana untuk memprediksi kematian pada anak dengan pneumonia. Analisis statistik dilakukan dengan program SPSS 20.

Penelitian ini telah mendapatkan persetujuan dari
Komite Etik Fakultas Kedokteran Universitas Gadjah Mada.

\section{Hasil}

Didapat 292 anak usia 2 bulan - 5 tahun dengan pneumonia dirawat di RSUP Dr. Sardjito selama periode penelitian. Enam puluh satu anak dieksklusi karena data yang tidak lengkap dan 6 anak karena infeksi HIV. Dari 225 anak yang memenuhi kriteria, $42(18,67 \%)$ meninggal dunia. Karakteristik subyek penelitian tertera pada Tabel 2. Sebagian besar anak (68\%) berusia $\geq 6$ bulan -5 tahun dengan proporsi lakilaki : perempuan adalah $1,25: 1$. Sebagian besar anak dengan gizi baik $(66,67 \%)$ dan $10,67 \%$ dengan gizi buruk. Rata-rata lama rawat inap 10 hari $( \pm$ SD 13,61).

\section{Prediktor kematian pneumonia}

Likelihood Ratio (LHR), crude weight, dan adjusted weight prediktor kematian tertera pada Tabel 3. Usia $<6$ bulan, takikardia, hipoksemia (SpO2 <92\%), anemia dan leukositosis memenuhi kriteria LHR untuk dimasukkan dalam perhitungan sistem skor (Tabel 4).

Tabel 2. Karakteristik subyek penelitian

\begin{tabular}{lc}
\hline Karakteristik & $\mathrm{n}=225$ \\
\hline Jenis kelamin, laki-laki, n (\%) & $125(55,56)$ \\
Usia, n (\%) & \\
$0-<6$ bulan & $72(32,00)$ \\
$\geq 6$ bulan -5 tahun & $153(38,67)$ \\
Rujukan, n (\%) & \\
Datang sendiri & $107(47,56)$ \\
$\quad$ Dokter umum/anak & $27(12,00)$ \\
Rumah sakit lain & $91(40,44)$ \\
Status gizi, n (\%) & \\
Baik & $150(66,67)$ \\
Kurang & $50(22,22)$ \\
Buruk & $24(10,67)$ \\
Lebih & $1(0,44)$ \\
Lama rawat inap (hari), n (\%) & \\
$\quad$ 7 & $126(56,00)$ \\
$>7$ & $99(44,00)$ \\
Luaran, n (\%) & \\
Hidup & $183(81,33)$ \\
Meninggal & $42(18,67)$ \\
\hline
\end{tabular}


Ambarsari S. N. Latumahina dkk: Skor prediksi kematian pneumonia pada anak usia di bawah lima tahun

Tabel 3. LHR, crude weight, dan adjusted weight skor prediksi kematian pneumonia

\begin{tabular}{lccccc}
\hline $\begin{array}{l}\text { Prediktor } \\
\text { kematian }\end{array}$ & $\begin{array}{c}\text { Mati } \\
(\mathrm{n}=42)\end{array}$ & $\begin{array}{c}\text { Hidup } \\
(\mathrm{n}=183)\end{array}$ & LHR & $\begin{array}{c}\text { Crude } \\
\text { weight }\end{array}$ & $\begin{array}{c}\text { Adjusted } \\
\text { weight }\end{array}$ \\
\hline $\begin{array}{l}\text { Usia (bulan) } \\
<6\end{array}$ & 23 & 49 & 2,05 & 3 & 5 \\
$\quad>6$ & 19 & 134 & 0,62 & 0 & 0 \\
$\quad \begin{array}{l}\text { Takikardia } \\
\quad \text { Ada }\end{array}$ & 31 & 64 & 2,11 & 3 & 6 \\
$\quad$ Tidak & 11 & 119 & 0,4 & -4 & -8 \\
Hipoksemia & & & & & \\
$\quad$ Ada & 14 & 24 & 2,54 & 4 & 3 \\
$\quad$ Tidak & 28 & 159 & 0,77 & 0 & 0 \\
Anemia & & & & & \\
Ada & 33 & 79 & 1,82 & 3 & 4 \\
$\quad$ Tidak & 9 & 104 & 0,38 & -4 & -6 \\
Leukositosis & & & & & \\
Ada & 22 & 47 & 2,04 & 3 & 3 \\
Tidak & 20 & 136 & 0,64 & 0 & 0 \\
\hline
\end{tabular}

Tabel 4. Skor prediksi kematian pneumonia (SPKP)

\begin{tabular}{lcc}
\hline Prediktor & Kategori & Skor \\
\hline Usia (bulan) & $<6$ & 5 \\
& $>6$ & 0 \\
Takikardia & Ada & 6 \\
& Tidak & -8 \\
Hipoksemia & Ada & 3 \\
& Tidak & 0 \\
Anemia & Ada & 4 \\
& Tidak & -6 \\
Leukositosis & Ada & 3 \\
& Tidak & 0 \\
\hline
\end{tabular}

Total skor dari nilai skor prediksi kematian pneumonia berkisar antara -14 sampai 21.

Cut off point dari skor total untuk memprediksi kematian karena pneumonia ditentukan dengan kurva receiver operating characteristics (ROC) seperti tertera pada Gambar 1. Kurva ROC dari sistem skor ini memiliki nilai AUC 0,84 (IK95\%: 0,77-0,90), yang menunjukkan nilai akurasi yang tinggi. Skor $\geq 3$ mempunyai sensitivitas $85,7 \%$ dan spesifisitas $72,1 \%$.

\section{Pembahasan}

Di antara 292 anak usia 2 bulan - 5 tahun dengan pneumonia, 18,67\% meninggal. Angka kematian tersebut mendekati angka estimasi WHO tahun 2013, yaitu 15\%. (GAPPD, 2013) Beberapa penelitian di India pada anak usia $1-59$ bulan yang dirawat di rumah sakit karena pneumonia melaporkan angka kematian berkisar antara $8,2 \%$ sampai $47 \%,{ }^{12,13}$ sedangkan penelitian di Lombok, Indonesia, melaporkan antara $3,4 \%$ sampai $12 \% .^{14}$

Penelitian kami mengidentifikasi usia $<6$ bulan, takikardi, hipoksemia ( $\mathrm{SpO} 2<92 \%)$, anemia dan leukositosis sebagai faktor risiko kematian yang bermakna dan berdasarkan hasil analisis dengan metode Spiegelhalter Knill-Jones, variabel-variabel tersebut dipakai untuk menyusun SPKP. Usia muda termasuk salah satu variabel yang penting untuk prediksi kematian pneumonia. Hal ini mungkin terkait dengan sistem imunitas yang belum sempurna, yang meningkatkan risiko kematian. Peningkatan angka 


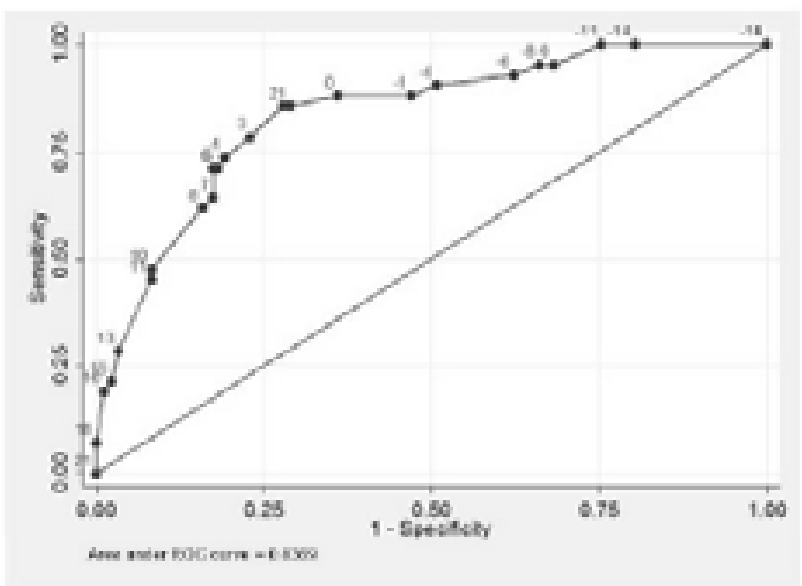

Gambar 1. Kurva ROC untuk skor prediksi kematian pneumonia

leukosit dapat menunjukkan adanya infeksi bakteri. Angka kematian pneumonia karena bakteri lebih tinggi dibandingkan pneumonia karena virus. Kondisi anemia, terkait fungsi hemoglobin sebagai transpor oksigen, transport oksigen ke seluruh tubuh berkurang. Pneumonia akan menyebabkan hipoksia dan kondisi anemia pada pneumonia dapat memperburuk kondisi hipoksia tersebut dan menyebabkan risiko kematian yang lebih tinggi. Anemia sebagai prediktor kematian konsisten dengan penelitian yang dilaporkan oleh Ivijanthi dkk. ${ }^{15}$

Sistem skor serupa telah dikembangkan di Afrika Selatan, yaitu the respiratory index of severity in children score (RISC). ${ }^{16}$ Sistem skor tersebut mempunyai tujuan yang sama, yaitu untuk memprediksi kematian pada anak usia muda dengan infeksi saluran pernapasan bawah, tetapi variabel yang dimasukkan dalam sistem skor ini berbeda. Variabel yang dievaluasi dalam RISC meliputi saturasi oksigen yang rendah (skor=3), retraksi dinding dada (skor=2), mengi (skor=-2), menolak makan (skor $=1$ ), berat badan sesuai usia dengan $z$ score: $\mathrm{z} \leq-3$ (skor=2), $-2 \leq \mathrm{z}<-3$ (skor=1), $\mathrm{z}>-2$ (skor=0). Skor total 6 dipakai sebagai cut off point untuk memprediksi kematian akibat pneumonia dengan area under $R O C$ curve $=0,923$ dan nilai $\mathrm{p}=0,87$. Variabel pada sistem skor kami berbeda dengan RISC karena beberapa kemungkinan. Pertama, karena pendekatan analisis statistik yang digunakan berbeda, di Afrika Selatan dengan analisis regresi logistik multivariat sedangkan pada penelitian kami menggunakan metode Spiegelhalter Knill-Jones. Kemungkinan kedua karena perbedaan karakteristik demografi pasien dan kriteria yang digunakan untuk diagnosis pneumonia.

Skor kematian pneumonia kami disusun berdasarkan tanda-tanda klinis dan pemeriksaan laboratorium yang sederhana yang dapat dilakukan oleh tenaga kesehatan di Rumah Sakit Kabupaten atau Puskesmas dengan rawat inap. Pemeriksaan SpO2 bisa menjadi salah satu kendala implementasi penggunaan sistem skor ini di daerah dengan fasilitas pelayanan kesehatan (fasyankes) yang terbatas karena tidak tersedianya pulse oximetry. Pemeriksaan SpO2 dengan pulse oxymetri sebenarnya merupakan cara yang obyektif untuk menentukan apakah seorang anak dengan pneumonia memerlukan terapi oksigen, yang merupakan salah satu kunci keberhasilan penanganan anak dengan pneumonia, disamping pemberian antibiotika. Saturasi oksigen yang rendah juga merupakan salah satu variabel pada RICS. Djelantik $\mathrm{dkk}^{14}$ juga melaporkan bahwa usia $<4$ bulan dan hipoksia (SpO2 <85\%) mempunyai risiko kematian 5,6 kali lebih besar dibandingkan dengan mereka yang tidak memiliki kedua faktor tersebut. Hal tersebut menunjukkan bahwa pemeriksaan obyektif SpO2 dengan pulse oxymetri seyogyanya merupakan pemeriksaan rutin yang dilakukan pada semua anak dengan pneumonia di fasyankes, baik tingkat primer, sekunder maupun tersier.

Kelebihan penggunaan SPKP untuk fasyankes di Indonesia adalah SPKP disusun berdasarkan data lokal. Namun demikian, penelitian kami memiliki beberapa keterbatasan. Pertama, penelitian ini dilakukan secara retrospektif dengan menggunakan data dari rekam medis. Kedua, penelitian ini dilakukan di rumah sakit tersier dengan kondisi berbeda dengan fasyankes primer atau sekunder. Oleh karena itu perlu dilakukan validasi skor prediksi kematian ini di setting yang berbeda.

\section{Kesimpulan}

Skor prediksi kematian pneumonia $\geq 3$ dapat digunakan untuk memprediksi kematian pada anak usia 2 bulan -5 tahun dengan pneumonia.

\section{Daftar pustaka}

1. Rahajoe NN, Supriyatno B, Setyanto DB. Buku Ajar Respirologi anak, Jakarta: Badan Penerbit Ikatan Dokter Anak 
Indonesia; 2010.h.350-65.

2. World Health Organization. Epidemiology and etiology of childhood pneumonia. Bull WHO 2008;86:408-16.

3. Ditjen PP \& PL Kementrian Kesehatan Republik Indonesia. Profil kesehatan Indonesia Tahun 2013. Jakarta: Kemkes RI; 2014.

4. McIntosh, K. Community acquired pneumonia in children: current concepts. N Engl J Med 2002;346:429-37.

5. Bradley JS, Byington CL, Shah SS. Executive summary: the management of community-acquired pneumonia in infants and children older than 3 months of age: clinical practice guidelines by the Pediatric Infectious Diseases Society and the Infectious Diseases Society of America. Clin Infect Dis 2011;53:617-30.

6. Brogan TV, Hall M, Williams DJ. Variability in processes of care and outcomes among children hospitalized with community-acquired pneumonia. Pediatr Infect Dis J 2012;31:1036-41.

7. Williams DJ. Association of white blood cell count and C-reactive protein with outcomes in children hospitalized for community-acquired pneumonia. Pediatr Infect Dis J 2015;34:792-3.

8. Capelastegui A, Espana PP, Quintana JM, Areito I, Gorordo I, Egurrola, dkk. Validation of a predictive rule for the management of community-acquired pneumonia. Eur Res J 2006;27:151-7.

9. Leowski J. Mortality from acute respiratory infections in children under 5 years of age: global estimates. World Health Stat Q 1986;39:138-44

10. Sonego M, Pellegrin MC, Becker G, Lazzerini M. Risk factors for mortality from acute lower respiratory infections (ALRI) in children under five years of age in low and middle income countries: a systematic review and meta-analysis of observational studies. PLoS ONE 2015;10:1-17.

11. Kisworini P, Setyati A, Sutaryo. Mortality predictors of pneumonia in children. Paediatrica Indonesiana 2010;50:14953.

12. Ramachandran P, Nedunchelian K, Vengatesan A, Suresh S. Risk factors for mortality in community acquired pneumonia among children aged 1-59 months admitted in a referred hospital. Indian Pediatr 2012;48:889-95.

13. Tiewsoh K, Lodha R, Pandey RM, Broor S, Kalaivani M, Kabra SK. Factors determining the outcome of children hospitalized with severe pneumonia. BMC Pediatrics 2009;9:15.

14. Djelantik IG, Gessner BD, Sutanto A, Steinhoff M, Linehan M, Moulton LH, dkk. Case fatality proportions and predictive factors for mortality among children hospitalized with severe pneumonia in a rural developing country setting. J Trop Pediatr 2003;49:327-32.

15. Ivijanthi MQ, Vitri S, Landia S, Makmuri MS. Risk factors of mortality in children under 6 year old with pneumonia. Presented at $13^{\text {th }}$ National Child Health Congress, Bandung, 2005.

16. Reed C, Madhi SA, Klugman KP, Kuwanda L, Ortiz JR, Finelli $\mathrm{L}$, dkk. Development of the respiratory index of severity in children (RISC) score among young children with respiratory infections in South Africa. PLoS ONE 2012;7:e27793.

17. Seymour DG, Green M, Vaz FG. Making better decisions: construction of clinical scoring systems by the SpiegelhalterKnill-Jones approach. BMJ 1990;300:223-6.

18. Spiegelhalter DJ, Knill-Jones RP. Statistical and knowledegebased approaches to clinical decision-support system, with an application in gastroenterology. J Royal Statist Soc A 1984;147:35-77.

19. Knill-Jones RP. Diagnostic systems as an aid to clinical decision making. Br Med J 1987;295:1392-6. 